\title{
Recurrent Toxocariasis Due to Chronic Urticaria and Successful Treatment with Prolonged Albendazole Therapy
}

\author{
Kronik Ürtikere Neden Olan ve Uzatılmış Albendazol Kullanımı ile Başarılı Bir Şekilde \\ Tedavi Edilen Rekürren Toxocariasis Olgusu
}

\section{Ergenekon Karagöz , Mehmet Burak Selek², Ersin Aydın³, Mustafa Hatipoğlư1, Vedat Turhan, Ali Acar' ${ }^{1}$ Oral Öncül', Levent Görenek}

'Department of Infectious, Diseases and Microbiology, GATA Haydarpaşa Training Hospital, İstanbul, Turkey

2Department of Medical Microbiology, GATA Haydarpaşa Training Hospital, İstanbul, Turkey

${ }^{3}$ Department of Dermatovenerologic Diseases, GATA Haydarpaşa Training Hospital, İstanbul, Turkey

\begin{abstract}
Toxocariasis is a worldwide human helminthiasis, especially seen in temperate and tropical climate regions around the world. The diagnosis of this disease is performed on the basis of clinical symptoms and laboratory findings. Albendazole is one of the treatment choices for toxocariasis, with a currently recommended regimen of $10 \mathrm{mg} / \mathrm{kg} /$ day in two doses (400 mg twice daily) for 5 days. However, there is no precise consensus about the duration of the treatment. In this article, we report a case of toxocariasis; the patient visited our infectious disease polyclinic with complaints of long-term itching and urticarial skin lesions that were resistant to routine treatment and that recurred. Then, recurrent disease was resolved and skin lesions were diminished after prolonged albendazole therapy. (Turkiye Parazitol Derg 2015; 39: 83-5)
\end{abstract}

Keywords: Chronic urticaria, toxocariasis, prolonged albendazole therapy

Received: 22 Ağustos 2013

Accepted: 29 Ağustos 2014

\section{ÖZET}

Toxocariasis, dünya genelinde özellikle ılıman ve tropikal iklimin hüküm sürdüğü bölgelerde görülen bir paraziter hastalıktır. Tanı klinik ve laboratuar bulguları ile konur. Albendazol (400 mg günde iki kez) 10 mg/kg/gün 5 gün süre ile kullanımı önerilen tedavi rejimlerinden biridir. Ancak, tedavi süresi ile ilgili kesin bir konsensus mevcut değildir. Bu yazıda; rutin tedaviye dirençli ve tedaviye rağmen tekrarlayan, uzun süredir devam eden kaşıntı ve ürtikeryal cilt lezyonları ile enfeksiyon hastalıkları polikliniğine başvuran ve uzatılmış albendazol tedavisi sonucu kür sağlanan bir Toxocariasis olgusu sunulmuştur.(Turkiye Parazitol Derg 2015; 39: 83-5)

Anahtar Sözcükler: Kronik ürtiker, toxocariasis, uzatılmış albendazol tedavisi

Geliş Tarihi: 22 Ağustos $2013 \quad$ Kabul Tarihi: 29 Ağustos 2014

Address for Correspondence / Yazışma Adresi: Dr. Ergenekon Karagöz, Department of Infectious, Diseases and Microbiology, GATA Haydarpaşa Training Hospital, İstanbul, Turkey. Phone: +90 5071425910 E-mail: ergenekonkaragoz@hotmail.com DOI: 10.5152/tpd.2015.3285

CTelif hakkı 2015 Türkiye Parazitoloji Derneği - Makale metnine www.tparazitolderg.org web sayfasından ulaşılabilir. CCopyright 2015 Turkish Society for Parasitology - Available online at www.tparazitolderg.org 


\section{INTRODUCTION}

Toxocariosis is a worldwide human helminthiasis, particularly occurring in temperate and tropical climate regions worldwide (1). Dogs are reservoirs for the spread of this disease. Thus, children who play with dogs without paying attention to hygiene and who have habit of hand-to-mouth and inadvertent ingestion of soil are at risk (1). The following clinical entities have been recognized in humans: visceral larva migrans, ocular larva migrans, and covert toxocariasis. Visceral larva migrans presents with fever, hepatomegaly, and pulmonary findings. Ocular larva migrans especially affects older children and although it does not have systemic symptoms, it can lead to blindness. In covert toxocariasis, the symptoms are nonspecific (2). The diagnosis is made on the basis of clinical symptoms and laboratory findings. Here, we report a case of toxocariasis; the patient visited our infectious disease polyclinic with complaints of long-term itching and urticarial skin lesions that were resistant to routine treatment.

\section{CASE REPORT}

A 31-year-old man was admitted to our hospital with complaints of itching and embossed skin lesions characterized by erythematous and edematous plaques. He had experienced these symptoms for 2 years, and they especially appeared in the evening. Because of these complaints, he had visited internal medicine and allergy polyclinics and received treatment with antihistamine, with a diagnosis of chronic urticaria. Despite these treatments, his complaints did not disappear after 6 months. It was also learnt that in 2010 and 2011, he had visited the infectious disease and hematology polyclinics because of abdominal pain and thrombocytopenia. After detection of thrombocytopenia and splenomegaly, a bone marrow biopsy revealed normocellular bone marrow by the hematology service and he was discharged. His physical examination showed a body temperature of $36^{\circ} \mathrm{C}$, pulse of 75 beats/min, and blood pressure of $120 / 80$ $\mathrm{mm} \mathrm{Hg}$. In both shoulders and the right upper quadrant of the abdomen, there were puffy, erythematous, pruritic urticarial skin lesions; systemic examination was otherwise normal. The patient was hospitalized because of high titers of Toxocara canis excretory-secretory enzyme-linked immunosorbent assay (TES-ELISA) IgG NovaLisa NOVATEC (Immundiagnostica GMBH, Germany) twice. Laboratory findings were notable for leukocytes: 4,130/

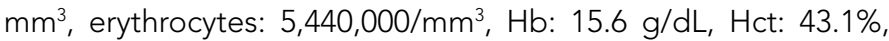
thrombocytes: $100,000 / \mathrm{mm}^{3}$, erythrocyte sedimentation rate: 2 mm/h, PT: $13.3 \mathrm{~s}$, C-reactive protein: $5 \mathrm{mg} / \mathrm{L}, \mathrm{AST}: 32 \mathrm{U} / \mathrm{L}, \mathrm{ALT}: 30$ $\mathrm{U} / \mathrm{L}$, BUN: $25 \mathrm{mg} / \mathrm{dL}$, and creatinine: $0.9 \mathrm{mg} / \mathrm{dL}$. Peripheral eosinophil count and total IgE levels were normal in the automated system. A peripheral blood smear revealed $85 \%$ neutrophils, $12 \%$ lymphocytes, $3 \%$ monocytes, and no eosinophilia. Urinalysis and stool examination revealed no abnormalities. In feces, parasitic investigation, and stool culture, no pathogenic microorganisms were detected. Organomegaly and no granulomas were determined on abdominal USG and no abnormality was observed on chest radiography. Ophthalmological, neurological, and respiratory system aspects were evaluated as usual. Serological tests were negative for HBsAg, anti-HCV, salmonellosis, brucellosis, and toxoplasma IgM and toxoplasma IgG.
When we measured the T. canis larva EIS antigen-specific IgG using an ELISA kit, we observed seropositivity with high titers. The punch biopsy of the urticarial skin lesions on the right leg of the patient was reported as being compatible with leukocytoclastic vasculitis (Figure 1). When we deeply researched his medical history, we learnt that one of his close friends had a dog in his house and our patient visited him frequently. After the investigations to confirm the diagnosis, we identified toxocariasis IG antigens by Western blot and initiated treatment with albendazole $(400 \mathrm{mg}$ ) twice a day for 5 days; the patient was then discharged. The patient's skin lesions regressed within 5 days of treatment with albendazole. But 3 months after the standard treatment, he returned to our polyclinic with the same complaints. We suspected the recurrence or inadequate treatment of toxocariasis and prescribed albendazole $(400 \mathrm{mg}$ ) once daily. After an additional 3 weeks of treatment, his skin lesions diminished dramatically. In addition, at the time of writing this paper, episodes of urticaria have not been observed for the last 12 months. Written informed consent was obtained from the patient for publication of this case report.

\section{DISCUSSION}

Toxocariasis is the dog intestinal roundworm and is usually manifested as visceral larva migrans. Humans are infected by ingestion of embryonated eggs in soil, via contaminated hands, or by consumption of unwashed vegetables. The embryonated eggs hatch in the intestine of a human host, liberating the larva, which in turn, penetrate the bowel wall and enter the circulation and migrate to the tissues and organs (3). They may cause granulomas. Although the granulomas are mostly seen in the liver, accompanying lesions are also frequently seen in the eyes. The brain, kidney, lung, and central nervous system involvements may also be seen. Eosinophilia may sometimes be the only finding, so the infection may be suspected in all children who have a history of soil ingestion with a high peripheral blood eosinophilia. Seroprevalence of toxocariasis has been reported in different regions with different rates. The highest seroprevalence is reported in Saint Lucia, with a rate of $86 \%$.

The clinical diagnosis of human toxocariasis depends on serological and immunological tests. In our case, the patient applied to our polyclinic with chronic urticaria and we suspected parasitic infections among the differential diagnoses. Punch biopsy of the skin was performed and a STES-ELISA serological technique was performed for the diagnosis of the disease; however, TESELISA is not specific because of cross-reactivity with parasites of other nematodes. Therefore, we confirmed the diagnosis of $T$. canis by Western blot (Toxocara WB IgG, Ldbio Diagnostics, France), which is a highly specific and confirmatory test for $T$. canis. In addition, the presence of low-molecular-weight bands in the range of 24-35 kDa indicates specific anti-Toxocara lgG in the sample (4). We observed low-molecular-weight bands in the range of 24-35 kDa in the Western blot analysis.

Nephrotic syndrome, HSV, endomyocarditis, and thrombocytosis cases are also described with a $T$. canis infection $(5,6)$. All these cases were treated successfully with anthelmintic agents. Albendazole is one of the treatment choices for toxocariasis, with a currently recommended regimen of $10 \mathrm{mg} / \mathrm{kg} /$ day in two 


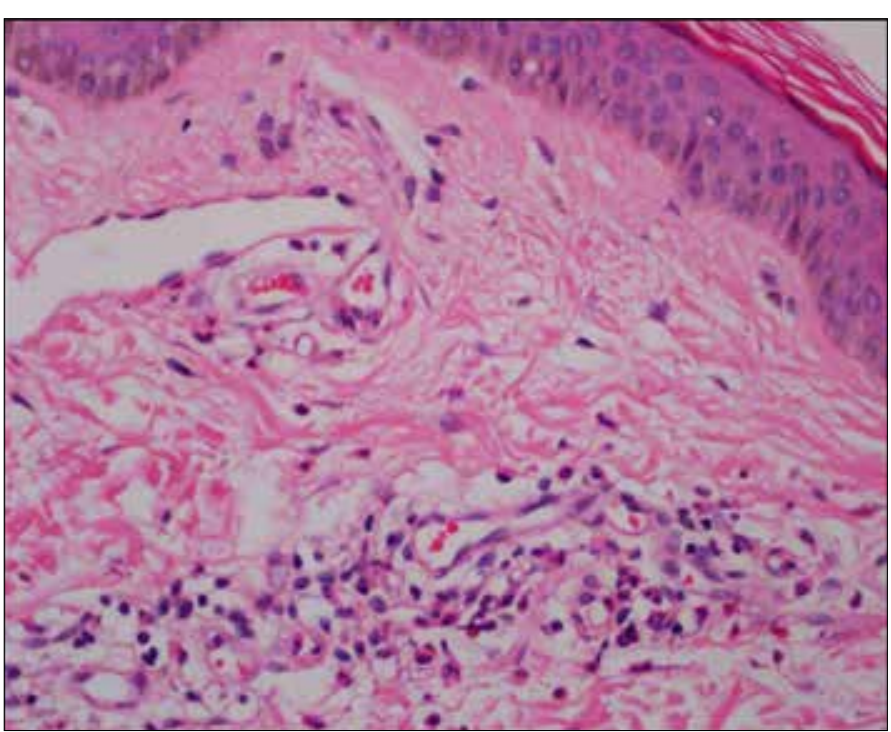

Figure 1. Leukocytoclastic vasculitis

doses (400 mg twice daily) for 5 days (7). Interestingly, recent clinical studies have shown that only a few patients, six of 19 $(32 \%)$, are cured after 5 days of albendazole therapy $(8,9)$. Instead, in Japan, adults who contract toxocariasis (typically through eating raw liver) are treated with albendazole for 4 weeks or longer (8). Kim et al. reported a case of recurrent toxocariasis that was also treated with an additional 3-week treatment (10). In our case, the patient was treated with albendazole (400 mg) twice daily for 5 days. Despite this treatment, his skin lesions recurred. Then, recurrent disease was resolved and skin lesions were diminished after prolonged albendazole treatment.

\section{CONCLUSION}

We conclude that toxocariasis, which is a parasitic infection, should always be considered in the differential diagnosis of chronic urticaria. Although 3 weeks of treatment was effective for our patient, it cannot be considered as a certain consensus for all cases. More study is required to reach a consensus on the appropriate duration of albendazole therapy to treat this disease.

Informed Consent: Written informed consent was obtained from the patient.

Peer-review: Externally peer-reviewed.

Author Contributions: Consept - E.K., M.B.S; Design - V.T., E.K.; Supervision - L.G.; Funding - M.B.S.; Materials - M.B.S.; Data Collection and/or Processing - E.K., A.A.; Analysis and/or Interpretation - O.Ö., E.A.; Literature Review - E.K., M.B.S., M.H.; Writer - E.K.; Critical Review - M.B.S.

Acknowledgements: We would like to thank Prof. Dr. Sami Öztürk from the Department of Allergy and Immunology, GATA
Haydarpaşa Training Hospital, Istanbul/TR for his valuable contributions.

Conflict of Interest: No conflict of interest was declared by the authors.

Financial Disclosure: The authors declared that this study has received no financial support.

Hasta onamı: Yazılı hasta onamı hastadan alınmıştır.

Hakem Değerlendirmesi: Dış Bağımsız.

Yazar Katkıları: Fikir - E.K., M.B.S.; Tasarım - V.T., E.K.; Denetleme - L.G.; Kaynaklar - M.B.S.; Malzemeler - M.B.S.; Veri Toplanması ve/veya işlemesi - E.K., A.A.; Analiz ve/veya Yorum - O.Ö. , E.A.; Literatür taraması - E.K., M.B.S., M.H.; Yazıyı Yazan - E.K.; Eleştirel inceleme - M.B.S.

Teşekkür: GATA Haydarpaşa Eğitim Hastanesi Allerji ve Immünoloji Servisi'nde görev yapan Prof. Dr. Sami Öztürk'e değerli katkılarından dolayı teşekkür ediyoruz.

Çıkar Çatışması: Yazarlar çıkar çatışması bildirmemişlerdir.

Finansal Destek: Yazarlar bu çalışma için finansal destek almadıklarını beyan etmişlerdir.

\section{REFERENCES}

1. Hayashi E, Tuda J, Imada M, Akao N, Fujita K. The high prevalence of asymptomatic Toxocara infection among schoolchildren in Manado, Indonesia. Southeast Asian J Trop Med Public Health 2005; 36: 1399-1406

2. Arango.C.A. Visseral Larva Migrans and the hypereosinophilia Syndrome. Southern Med J 1998; 91: 882-83. [CrossRef]

3. Winn W, Allen S, Janda W, Koneman E, Procop G, Schreckenberger $P$ editors. Miscellaneous Larval tissue parasite infections. Koneman's Color Atlas and Textbook of Diagnostic Microbiology. Sixth edition. Philedelphia: New Lippincott Williams and Wilkins; 2006.

4. Smith H, Holland C, Taylor M, Magnaval JF, Schantz P, Maizels R. How Common is Human Toxocariasis? Towards Standardizing Our Knowledge. Trends Parasitol 2009; 25: 182-88. [CrossRef]

5. Shetty AK, Aviles DH. Nephrotic syndrome associated with Toxocara canis infection. Ann Trop Paediatr 1999; 19: 297-300. [CrossRef]

6. Kagialis-Girard S, Mialou V, Ffrench M, Dupuis-Girod S, Pages MP, Bertrand Y. Thrombocytosis and toxocariasis:report of two pediatric cases. Pediatr Blood Cancer 2005; 44: 190-92. [CrossRef]

7. Magnaval JF, Glickman LT, Dorchies P, Morassin B. Highlights of human toxocariasis. Korean J Parasitol 2001; 39: 1-11. [CrossRef]

8. Yoshikawa M. Duration of treatment with albendazole for hepatic toxocariasis. Nat Clin Pract Gastroenterol Hepatol 2009; 6: E1-E2. [CrossRef]

9. Stürchler D, Schubarth $P$, Gualzata $M$, Gottstein $B$, Oettli A. Thiabendazole vs. albendazole in treatment of toxocariasis: a clinical trial. Ann Trop Med Parasitol 1989; 83: 473-78.

10. Kim MH, Jung JW, Kwon JW, Kim TW, Kim SH, Cho SH, et al. A case of recurrent toxocariasis presenting with urticaria. Allergy Asthma Immunol Res 2010; 2: 267-70. [CrossRef] 